
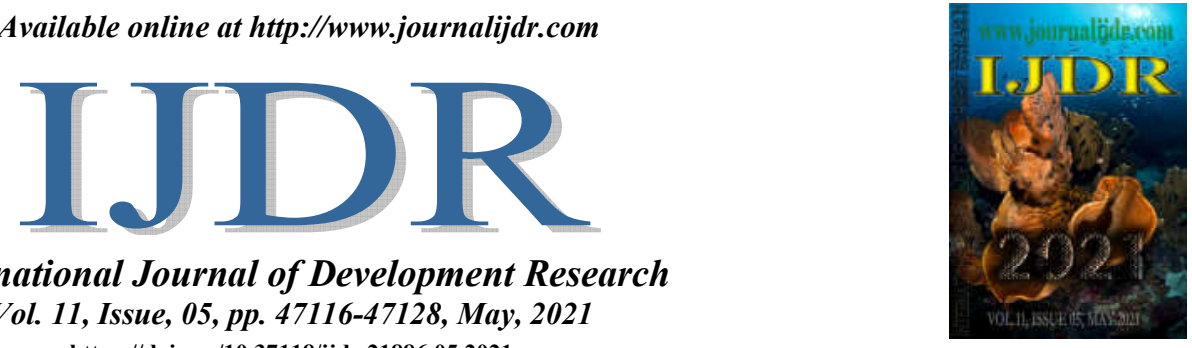

ISSN: 2230-9926

International Journal of Development Research

Vol. 11, Issue, 05, pp. 47116-47128, May, 2021

https://doi.org/10.37118/ijdr.21886.05.2021

\title{
METHODOLOGY FOR OPTIMIZING THE STOCK CONTROL OF AN ELECTRONIC SEGMENT COMPANY
}

\author{
*David Felipe Santos Oliveira and Jandecy Cabral Leite
}

\author{
Graduate Program in Process Engineering at the Institute of Technology of the Federal University of Pará
}

(PPGEP/ITEC/UFPA)

\section{ARTICLE INFO}

\section{Article History:}

Received $17^{\text {th }}$ February, 2021

Received in revised form

$19^{\text {th }}$ March, 2021

Accepted 20 ${ }^{\text {th }}$ April, 2021

Published online $30^{\text {th }}$ May, 2021

\section{Key Words:}

Management, Inventory, Methodology,

Electronic segment.

*Corresponding author:

David Felipe Santos Oliveira

\begin{abstract}
Inventory control management is considered a fundamental tool for the management of a company, since it allows processes to be managed efficiently. With less resources and more savings. This study aims to: identify and model the inventory control processes that already exist in the company, analyze the inventory that already exists in the company, describe the methodology for inventory control and propose actions of the methodology that allow corrections of inventory activities already identified. The goal is to propose a methodology for optimizing stock control that is able to define how much and when to buy products. The materials and methods applied in the execution of the work were divided into the following four stages: data collection, process mapping, analysis of improvement opportunities, research design, as well as guidelines for the application of the case study and implementation of the proposal for improvements. The results achieved allowed for the implementation of the methodology, where a $30 \%$ reduction in the problems of non-attendance was allowed. Also as a contribution were the goals to be achieved as positive factors such as lean inventory, improvements to efficient customer service, increased capital turnover and increased company profits.
\end{abstract}

Copyright (C) 2021, David Felipe Santos Oliveira and Jandecy Cabral Leite. This is an open access article distributed under the Creative Commons Attribution License, which permits unrestricted use, distribution, and reproduction in any medium, provided the original work is properly cited.

Citation: David Felipe Santos Oliveira and Jandecy Cabral Leite. 2021. "Methodology for optimizing the stock control of an electronic segment company", International Journal of Development Research, 11, (05), 47116-47128.

\section{INTRODUCTION}

Stores that sell electronics products are in a favorable situation for growth. The billing of the electronics industry reached $\mathrm{R} \$ 146.1$ billion in 2018, a nominal growth of $7 \%$ in relation to 2017 . This result represented a real increase of $1 \%$, discounting the inflation of the sector which, according to the Producer Price Index - IPP of the IBGE, was $6 \%$, according to [1]. In order to accompany this growth, it is essential that the companies that sell these articles are concerned with the processes adopted in the management of inventory maintenance, as they are essential for these companies. Since, by valuing business logistics through inventory management, greater reliability and profitability can be offered to the processes destined to the services of the company and its consumers. The constant increase in market competitiveness requires lean inventories, fast deliveries and lower costs [2]. Effective stock planning reduces the amounts involved in the process, it is beneficial to keep stocks low, respecting safety levels to meet demand. Inventory management strategies should only accept the inventory accumulation justification, when these products have low cost and long useful life [3] [4]. According to [5], the competitive market compels managers to develop a higher productivity of the assets that are in stock. The goal is to maintain a lean inventory, producing more with less resources.
For [6], business organizations prioritize developing management practices and productive strategies, aiming at a competitive market, minimizing production costs, reducing waste and enhancing profits. It is highly recommended to manage products in stock so that the activities performed by the companies are maintained and the processes are not paralyzed or compromised. Therefore, [7] argues that the stock should be sized to meet the production or sales chain without excess or lack of items. With this control, purchases can be made efficiently and, consequently, avoid increases in the sale price of the products, since the cost can be calculated in such a way as to improve the investment, increasing the efficiency of the fixed asset. Retailers control their companies' inventory levels by placing an order when it is ordered. As requested by the orders, the supplier proceeds to carry out the process to fulfill that order. This way of managing the supply chain optimizes costs and the uncertainty of adequately meeting the request for assets [8]. For [9], efficient inventory management generates imminent improvements, since it guarantees planned production, generates security in decision making and prevents loss of orders. To remedy poor management of inventory control, we sought to optimize the process to avoid or minimize errors in decisions related to inventory management. Through more efficient techniques that seek to assess and determine the levels of stocks defined as the maximum-minimum system, which consists of the following parameters according to [10]: (a) the 
minimum stock that you want to keep; (b) the time when new quantities of items must be purchased; (c) the time required to replace the item; (d) the number of items that must be purchased. Therefore, this work focuses on proposing a methodology for optimizing inventory control that seeks an efficient flow of products and thus transferring the lowest price to the consumer and leveraging improvements in sales. Considering that the companies to adapt to the globalization and the increase of the competitiveness of the market needed to present an adequate management of the stock control for the planning and success of small and big companies. Thus ensuring the effectiveness and efficiency of the company's operations. According to [11], inventory management is one of the most challenging topics to research due to its structural complexity, demonstrated through networks and research groups, and the complexity is induced by the uncertainty of demand and supply. The complication of sizing inventory makes it difficult to assertively use policies. The methodology of efficient actions for inventory control contributes to inventory management, as it offers the maximum reduction of product quantities, storage time, physical space and cost reduction. And thus increasing working capital, agility in customer service and the optimization of the institution's operational performance.

\section{LITERATURE REVIEW}

Stock: Inventory is a resource stored for a certain period, consisting of raw material or finished product waiting to be sold or used in production. (The stock is generated when the delivery of materials is higher than its use in production or output) [12] [13]. The stock is defined as any quantities of physical goods that are conserved, in an unproductive way, for some time interval [14]. According to [15], the objective of the stock is the temporary storage between supply and demand of finished products and the disposition of the components, parts and materials necessary to start production and material suppliers. Thus, the stock is any product or raw material that represents short- or long-term needs. Variables such as: sales losses, customer dissatisfaction with the lack of products, absence of raw materials for production negatively affect the performance of a company. For this reason, inventory management is essential for the positive results of business institutions [16]. [17], argues that a stock should be maintained at a low cost of production, since it is regularly costly to adjust the machines, so the production cycles need to have durability, reaching the purpose of low unit cost. However, it is essential to balance the costs of maintaining inventory. Another reason is to accommodate variations in demand, as demand for a product is never entirely regular, so it will vary in the short term, by season, etc.

Inventory Management: Inventory control has been studied since 1913 with Harris, since high maintenance costs have become evident. Currently, the main function of stock control is the handling between reducing inventory maintenance costs and satisfying customer demand [18]. [19] emphasize that business organizations that efficiently manage inventory management obtain excellent levels of customer service. And so some questions about when and how much to order is critical for inventory management, the answers to these questions define the policy and the appropriate system for inventory management [20]. Companies that value competitiveness invest sumptuous financial resources, time and qualified labor to obtain the precise management of inventory control. Effective handling of functions such as inventory management, order management, storage and transportation is all about good management offering competitive advantages to the company, making its products available to consumers faster and with lower values [21] [22]. Inventory management is essential for reducing and controlling costs, as well as enabling improvements in the level of services provided. The business organization aims to minimize its inventories as much as possible. However, an efficient stock management needs to guarantee the raw material or product requested on time [23]. According to [16], "integrated logistics is seen as the competence that links the company to its customers and suppliers". Thus, the complex logistical process has two complementary actions: the flow of materials and the flow of information. The logistics of a company is based on "the qualification of a company to provide the customer with a competitively superior service at the lowest possible cost". In the 70 's, other production control systems (MRP, JIT and ERP) emerged that have more qualitative characteristics in relation to traditional quantitative approaches, thus requiring a more dynamic inventory control ensuring lower costs. According to [24], the inventory management system known as (FIFO) - first in, first out-, aims that the products that are on sale follow the following rule: the first product to enter, will also be the first product to leave. For this reason, it is a mechanism widely used with perishable or short-lived goods.

According to [25], supply chain management uses inventory management as a balancing mechanism, with the objective of reducing the company's level of vulnerability and [26] emphasizes that supply chain management is based on reducing operating costs, determining the ideal time to produce a certain product and increase profits. However, the supply chain has three factors of uncertainty that stand out which are: suppliers, manufacturing and customers. Highlighting that the purpose of supply chain management is to specify the time and size of orders and to lessen the total cost [27]. According to [28], JIT (Just in Time) is a system widely used in production management that prioritizes that nothing should be produced, transported or purchased before the exact time. The Just in Time system characterizes inventories as a waste of resources, so they must be minimized. Keeping only the safety stocks to keep the production flow. Losses for companies with inventories generate costs and occupation of expendable space [29]. According [30], the main characteristics of the JIT system is pulled production, the raw material is requested as needed, these are delivered on the production line or to customers, thus providing greater quality control of components, elimination of waste and reduction storage cost. Thus, the term "just-in-time" is defined as a production strategy, which aims to serve the customer at the right time and in the precise quantity. This followed three basic principles of growth: building what is necessary, suppressing what does not integrate value and stopping if something goes wrong. Synthesizing the concept of JIT in producing and delivering products in time to be sold [31]. According to [32] the Just in time system recommends that the products are received in the exact quantity and at the time they are needed in production or sale. The ERP system (Enterprise Resource Planning) is an integrated package, aimed at a single and continuous flow of information from across the organization. According to [33], ERP consists of a tool that seeks to improve the process in production and purchases in real time. Therefore, the system allows the mapping and visualization of the broad scenario of the company's business. In the face of competitiveness, whether in large companies or in isolated companies, the cohesion of production systems with inventory management is of paramount importance. Since the stock is mostly seen as a high cost sector. According to [34], the correct management of the stock is to maximize the sales response effect and the rectification of the production planning. In order to decrease the capital invested in inventories, due to its high cost. However, inventory management aims to ensure the productive and commercial functioning of the company, currently configuring it as one of the most important sectors of the organization. According to [35], inventory management seeks a balance between supply and demand. Inventory decisions must be made in accordance with the strategy of each organization and financial sector. According to [10] one of the most effective techniques for studying and adjusting stock levels is the maximum-minimum system, which includes the following information:

(a) the minimum stock to be maintained;

(b) the time when new quantities of items must be purchased;

(c) the time required to replace the item;

(d) the number of items that must be purchased.

Minimum Stock: Minimum stock is defined as the minimum necessary quantity that a product or item can remain in stock 
according to its turnover and replacement time [36]. [37], shows that the greatest importance of the minimum stock in organizations is found in the execution of the calculation of the order point through the values obtained in the minimum stock. Therefore, the minimum stock cannot be high, because if so it does not justify its purpose. The quantity of the minimum stock is in accordance with the uncertainties of demand, replacement time and the degree of service that is intended to be offered to the customer [38].

According to [34], the minimum stock or reserve stock is the minimum quantity needed in stock, to guarantee the uninterrupted and efficient functioning of the production process or sales without the risk of financial losses. You can quantify the minimum stock in two ways:

a) Fixing a certain minimum projection;

b) Calculations and mathematical models;

The minimum stock can be represented by equation 1 [39].

$\operatorname{Emin}=\operatorname{Cmd} x K$

Where:

Emin $=$ Minimum Stock.

$\mathrm{Cmd}=$ Average monthly consumption

$\mathrm{K}=$ Degree of risk, that is, desired degree of coverage.

Method with Degree of Definitive Service (MGAD): The method with degree of definitive service can be used to calculate the quantity to be kept in stock [10]. For [40] the standard deviation of errors from previous assumptions should be used to define the variation in past demand. According to [41], the average consumption uses numerical sources previously collected, producing accurate information. To define the minimum stock by the MGAD method, the following steps are necessary:

a) calculate the average monthly consumption, according to equation 2 .

$C m d=(\Sigma C) / n$

Where:

Cmd $=$ Average monthly consumption;

$C=$ Consumo mensal do item;

$n=$ Número de períodos.

b) Calcular o desvio-padrão de consumo, por meio da equação 3 .

$\delta=\sqrt{\frac{\sum_{i=1}^{n}(C-C m d) 2}{n-1}}$

Onde:

$\delta=$ Desvio-padrão de consumo;

$\mathrm{C}=$ Monthly item consumption;

$\mathrm{Cmd}=$ Average monthly consumption;

$\mathrm{n}=$ Number of periods.

The level of service or attendance represents the probability that the stock will meet the demand requested at that exact moment of the order [42]. For [43], the service level should be measured by multiplying the service factor by the standard deviation. Also according to [10], with this model it is possible to compare values to serve the market with a greater or lesser degree of customer service, according to table 1 .

According to [44] to calculate the minimum stock, it is necessary to start from the consumption that the company intends to meet. This level of service consists of the relationship between the quantity served and the quantity needed, according to equation 4 .
Table 1 - Coefficient values for degrees of attendance with percentage risks. TRANSLATE AND TRANSFORM VALUES IN DOLLARS

\begin{tabular}{|l|l|l|l|l|l|}
\hline Risk (\%) & K & Risk (\%) & k & Risk (\%) & $\mathrm{k}$ \\
\hline 52,000 & 0,102 & 80,000 & 0,842 & 90,000 & 1,282 \\
\hline 55,000 & 0,126 & 85,000 & 1,036 & 95,000 & 1,645 \\
\hline 60,000 & 0,253 & 86,000 & 1,085 & 97,500 & 1,960 \\
\hline 65,000 & 0,385 & 87,000 & 1,134 & 98,000 & 2,082 \\
\hline 70,000 & 0,524 & 87,500 & 1,159 & 99,000 & 2,326 \\
\hline 75,000 & 0,674 & 88,000 & 1,184 & 99,50 & 2,576 \\
\hline 78,000 & & 90,000 & 1,233 & 99,90 & 3,090 \\
\hline
\end{tabular}

Source:[10].

$N A=\frac{n 1}{n 2}$

Where:

$\mathrm{NA}=$ Service Level

$\mathrm{n}_{1}=$ Quantity served

$\mathrm{n}_{2}=$ Quantity needed

Lot of shopping: Purchase lot (LC) is the number of items that make up the purchase order [10]. According to [37], economic lot also known as purchase lot is the optimal amount of purchase to be made. Based on accurate data collected from previous demands and resupply time for each product. The quantities of an item to be purchased always with the objective of reducing acquisition and storage costs define the concept of a purchase lot [45]. [46] emphasize that the purchase lot represents a strategy in inventory management that aims to identify the quantity of items needed in a given replenishment order. According to [47], the purchase lot is the indispensable quantity to maintain the supply of the stock, so that it can meet the consumption demands without jeopardizing the sales or the production flow of the business organization, according to equation 5 .

$L C=C m d$

Where:

$\mathrm{LC}=$ Lot of shopping.

Cmd $=$ Average monthly consumption.

Replacement time: The replacement time determines the period elapsed from the identification that the stock needs to be replenished until the material arrives at the organization. This data is of paramount importance for determining the order point [34].

Order point: Order point (PP) is the exact time to place a new order for a certain product, or several items, as needed. According to [48], the order time is specific for each product. According to variables such as replacement time and demand. For [49], the value of the order is impartial of the quantities of the items, but it comprises the necessary cost of making and receiving the order.

To quantify the PP, equation $6,[10]$ is used.

$P P=(C x T R)+E m i ́ n$

Where:

$\mathrm{PP}=$ Order point;

$\mathrm{C}=$ Monthly item consumption;

TR =Resupply time;

Emín =Minimum stock.

Maximum stock: Maximum stock is the result of the sum of the safety stock plus the purchase lot, that is, minimum stock plus the purchase lot. Determined in such a way that its volume dampens the normal variations of stock in the dynamic phase of the market. The purchase lot is the quantity of items requested from the order point [10]. According to [37], the maximum stock results from the sum between the safety stock and the purchase lot. It is characterized by 
the fact that it exceeds the safety stock in number of items. According to [36], the maximum stock is the number of items that the business organization is willing to keep in stock, a contact that does not harm the company's production line. The maximum stock can be represented by equation 7 :

$E m a ́ x=E S+L E C$

Where:

Emáx $=$ maximum stock.

$\mathrm{ES}=$ reserve or safety stock.

LEC $=$ economical buying lot.

Safety stock: According to [50], safety stock is the quantitative valueminimum number of items that need to be in stock to cover possible variations in the process, which may be: delays in delivery time, rejection of the purchase lot and increase in product demand. Its primary objective is not to harm the production process and, essentially, not to cause difficulties for customers due to the lack of items and, therefore, not to cause delays in product deliveries. The safety stock is a tool used to avoid lack of raw material or finished product [51]. The safety stock is one of the segments that interfere in the financial and competitive efficiency of the company. Anyway it is directly determined by the demand and supply of the product. The greater the fluctuation or uncertainty of demand, the greater the safety stock levels. Thus increasing the costs of maintaining the stock [52]. For [53], the safety stock protects the business organization from variations in excess demand and anticipated quantities in the production or purchase cycle. Factors such as economic crisis, climatic variations, political and social conflicts justify the maintenance of the security stock. Since the objective of the market is to serve the customer effectively in less time [42]. According to [54], reserve stock also known as safety stock has the purpose of covering up variations related to the demand and the specific supply time of each product. For [52], optimization of safety stock levels, offers a more precise control of the replacement time of a given product. Therefore, the purpose of the safety stock is to compensate for the uncertainties that guide the supply of demand. The safety stock has as main objective the neutralization of short-term variations in demands and resupply terms. According to [55], we can calculate safety stock according to equation 8 .

$\mathrm{ES}=\sqrt{L T *\left(\sigma_{d}\right)^{2}+d^{2} *\left(\sigma_{L T}\right)^{2}} * K$

Where:

Es $=$ Reserve or safety stock;

$\mathrm{d}=$ average demand

LT= supply time

$\mathrm{d}=$ consumption standard deviation

$\mathrm{k}=$ safety factor

$\sigma=$ sigma

Defined that the safety stock must be measured according to the consumption characteristics of each product [56].

ABC Classification: According to [15] the ABC classification is one of the most used methods for inventory management, it is based on monitoring the control of items individually. Also according to the author, for the inventory control management to be carried out efficiently, four questions must be answered, and the $\mathrm{ABC}$ system allows to answer the first two questions, determining the importance of the items and highlighting the different levels of control that each item needs:

a. How important is the item to the stock?

b. How are items controlled?

c. How many units should be ordered at a time?

d. When should an order be issued?
The $\mathrm{ABC}$ curve is an essential tool for managers, as it highlights which items require more attention and effective management in terms of administration. Following this discrimination, the classes of the $A B C$ curve can be defined as follows [34]. [57] shows that the $\mathrm{ABC}$ classification tool can be used in the most diverse commercial sectors, with items of different natures and units of measurement. According to [58], the $\mathrm{ABC}$ curve starts from the principle that the products that are in stock have importance that differs from each other, a principle defended in the Pareto diagram. Thus, the identification of the relevance of each item directs decision-making in the management of the stock. The ABC curve analysis is a system for classifying items according to their economic importance to the company. Allowing the identification of materials that should receive special attention regarding their administration [59] [46]. According to [60], the $\mathrm{ABC}$ curve is a tool that helps control inventory whether it is raw material or finished products, breaking them down into classes according to their financial return for the business institution. According to [61], it is observed in the analysis of the ABC curve, that the items that constitute the highest consumption are those that represent the part of the lowest percentage of the stock value. And that the items that comprise the part of the highest percentage of the stock's value are the ones that represent the smallest part of that stock. The ABC Curve is a method known as the $80 / 20$ rule, it is so called, because approximately $80 \%$ of the sales of a company or operation are responsible for only $20 \%$ of all types (products) of stocked items. Subsequently, represented by the Pareto curve, this tool allows us to classify the items of the stock studied in A, B or C (figure 1), based on their costs and quantities. Usually a small ratio of the total items contained in stock represents a large proportion of the total value in stock [35]. Therefore, enabling business managers to focus more vigorously on controlling the items that add the most profits to their shopping center:

a) Class A - $20 \%$ of high value items that represent about $80 \%$ of the total value of the stock.

b) Class B - $30 \%$ of the items that represent about $10 \%$ of the total value.

c) Class C - low value items that, despite comprising about $50 \%$ of the total items stocked, represent about $10 \%$ of the total value.

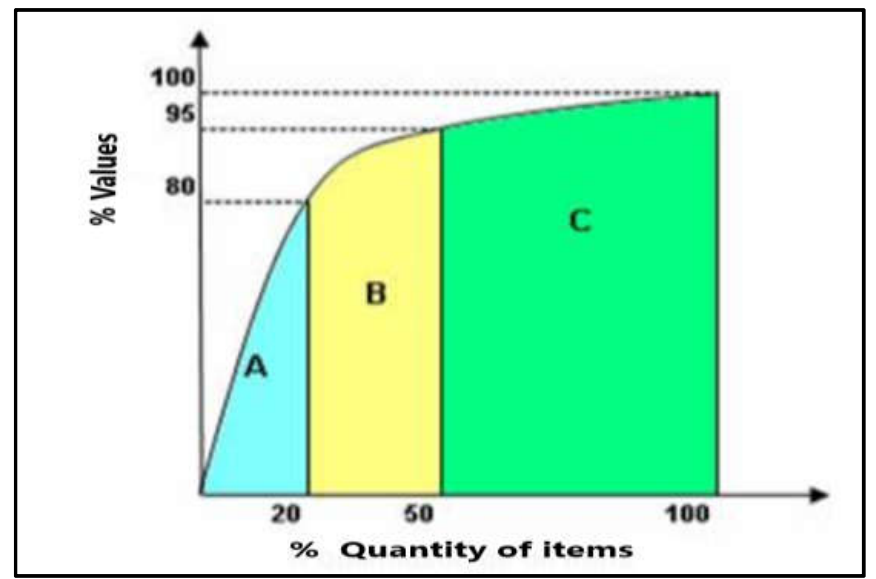

Source: [35]

Figure 1. Curve ABC

According to [62], the analysis of the Pareto curve is inevitable to optimize the benefit / cost ratio in an inventory control system. This analysis allows to classify the products in items of high importance (items of class A), items of medium importance (items of class B) and items of low importance (items of class C). According to [63], the $\mathrm{ABC}$ classification system is used to catalog and separate the most important items. Also defined as a statistical classification of products based on the Pareto principle.

Flowchart, Process Mapping and Modeling: The flowchart is an easy-to-use, low-cost, but highly efficient tool. It provides an overview of all the processes carried out individually in the 
organization, elucidating opportunities for increasing the efficiency and effectiveness of activities, according to [64]. [65], cites the advantages of using the flowchart in: it allows to verify how the components of a system are related, thus facilitating the analysis of its effectiveness. The visualization of the steps, operations and forms makes it possible to locate the faults and visualize the modifications introduced. [66], points out the flowchart as, graphically, the heart of process mapping, often used for information processing purposes. Therefore, the use of the flowchart in the commercial core of the company, results in cost reduction indices, since this tool improves the understanding of the buying and selling process, revealing the necessary steps to standardize activities. According to [67], it is argued that what is understood as a process is a series of activities that receives an input, adds value to it and produces a product or an outlet. The process comprises a set of interrelated activities, which are carried out manually or by machines that aim at one or more objectives. [68]. Process mapping is widely used to document existing processes. Extensively spreading in search of business process improvement, as it offers the benefit of transparency to the participants in the process [69]. [70], describes that the mapping of processes enables the understanding of a procedure through the construction of a map that should graphically highlight, in a model, the relationship between personal activities, information and objects involved. He evidenced that the first action to be taken is the framing of the process, thus identifying the suppliers, inputs, the process, the outputs and the customer, through the FEPSC technique (Supplier, Input, Process, Output and Customer Diagram). Modeling the problem is essential, since the purpose is to generate accurate assumptions. The system consists of data collection, analysis and treatment [51]. The modeling provides analytical data that clarifies exploratory scenarios, enabling the simulation of modeled systems in order to provide quantitative results and the financial performance of the agents. Therefore, the analysis of the modeling produces the tools that help the decision making. [71]. Inventory control management is a highly complex process, since it works with data variations. An efficient way to manage this heterogeneity is the dynamic modeling of the supply chain, which enables the design of the process. Allowing a better view for decision making in a more assertive way [72]. The execution of the process modeling is imminent because it allows a detailed study of the processes in business organizations. Since the definition of a process is a change of either a situation or a product. And modeling is conceptualized as precisely redesigning processes in stages [73] [74]. The modeling builds a model that relates the processes with their respective responsible and proposed objectives. In a precise way that offers an agile understanding of the process steps and their failures, if any [75]. The mapping of the process produces benefits such as the standardi zation and detailed documentation of the activities. It also offers a clear visualization of the integration of the processes, providing the opportunity to redesign the processes in order to reduce costs. According to [76], the process mapping provides information for the identification of activities, failures in the process and a different view of the correlation between the activities that form the process. The identification of processes and the quality of their performance is essential in modeling, therefore, it is necessary to carry out an efficient collection of information about activities through sources such as former employees, responsible for the actions and study of previously collected data [77]. For [6], mathematical modeling contributes to inventory management because it facilitates making decisions about how much, how, where and when to buy a certain product, minimizing waste in unnecessary purchases. According to [11] when modeling real-life systems, we should be aware that in reality, inventory management and shop floor management professionals have a variety of response options to ensure timely delivery customers and the timely completion of production orders.

\section{MATERIALS AND METHODS}

Research location, population and sample: The present case study was implemented from March 2019 to August 2019. This company is in the electronic components logistics sector, made up of 10 employees. Its competitors are large organizations, which have a greater tradition in the market. However, they have a centralized distribution center outside the municipality of Manaus, which increases the delivery time of the products, while the company studied has a local stock, thus taking advantage of the possibility of short-term delivery. Data collection was carried out with on-site visits, through dialogue with the company's manager and employees. The interviews were conducted with a questionnaire based on the demand management proposals analyzed in the study. The collected data arranged in electronic spreadsheets (Excel) were provided by the company in question. Obtaining this information, it was possible to analyze and, consequently, propose improvements in inventory management, with the primary purpose of meeting customer expectations and reducing the cost of inventory, while respecting the organization's capacity. Considering the selected techniques: observation, data sampling and study of stock management, the present work was mainly supported by bibliographic analyzes, which are the most important collection methods, with the purpose of understanding stock management in study, and the behavioral assumptions in the commercial branch of the studied company through the means provided by systematic observation, through which it was possible to verify the details that instructed the course of the research and the type of approach.

Research designs: The design of a survey (figure 2) depicts how the data will be obtained, analyzed and interpreted, that is, it is through design that there is a relationship between the results to be collected with the appropriate conclusions to the initial questions of the study [78]. In view of the above, the design of the present research, a research flowchart was generated showing the steps taken: review of bibliography, definition of the problem; definition of case study; data collect; data analysis; and finally conclusions found.

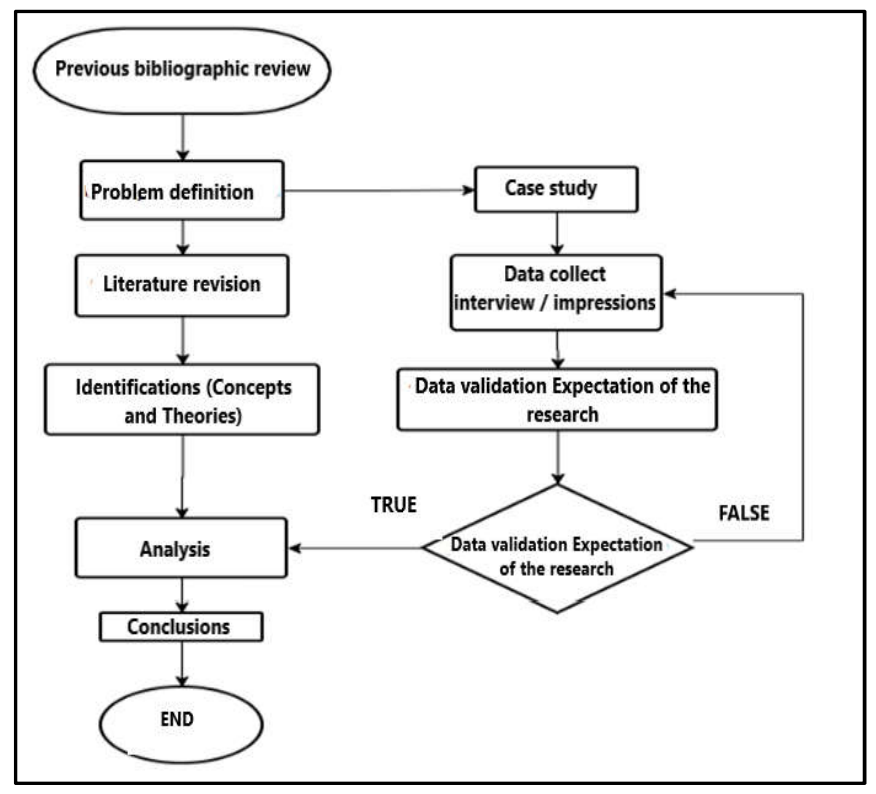

Source:Authors, (2021).

Figure 2. Research Flowchart Design

As for the purposes of the research and application of the case study: The work presented here had the final objective of proposing improvements in inventory management through the application of the methodology for the optimization of inventory control. Through the correct application of the calculations of the variables already discussed, evaluating the different commercial processes and looking for evidence of efficiency, specifically, with the minimum-maximum stock approach in the company studied in Manaus, with a strategy aimed at reducing costs with the management and inventory improvements. The methods employed here sought to incorporate reliable answers to the research purpose, trying to know and apply the studied company, its functionality in reducing unnecessary costs, surplus stock in the processes, in order to suggest the necessary changes influencing, in the end, efficiency demands and reducing 
costs themselves, accumulating and understanding inventory management. The methodology flowchart was developed taking into account the most eminent and precise variables, emphasizing each phase of the processes. And so, offering reliable and authentic data for each sector, optimizing the management process. According to this information, we defined the phases to be applied in the preparation of this case study divided into four steps, exemplified in the illustration in the flowchart of Figure 3.

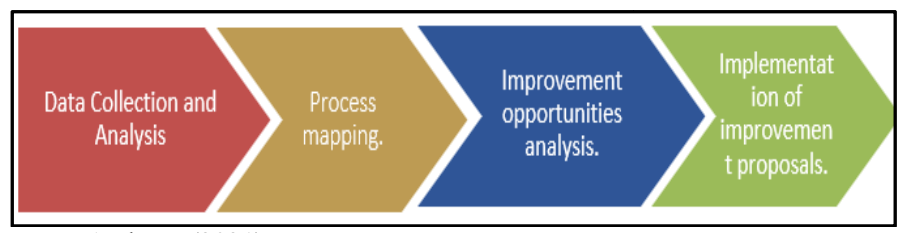

Fonte: Authors, (2021).

\section{Figure 3. Process flowchart}

Data collection and analysis: The company currently works with cash flow software for items in stock, however it has the functionality to control the entry and exit of products, and the printing of tax coupons, with no classification. In addition, no company employee has sufficient knowledge for the correct handling of the program, due to lack of interest and / or commitment. However, low inventories can cause, if not well managed, costs that are difficult to quantify in the face of delivery delays, production re-planning, customer dissatisfaction. Thus, there is a need for stability in inventory levels in order to balance sales, satisfy the customer and, consequently, increase profits.

\section{Mapping, process modeling, Analysis of improvement opportunities and Implementation of the improvement proposal: The modeling of the processes used the Bizagi Process Modeler software, which is free and uses the BPMN notation. BPMN was developed by the Business Process Management Initiative (BPMI), in an agreement established between some tool and modeling companies with different notations of their own, with the objective of creating a standardized language for modeling business processes that are easy for end users to understand. At this stage, improvements were perceived that could be proposed as a result of the employees' suggestions and abstractions of the problem analyzed within this project. Thus, some improvement items diagnosed in the proposed project were identified:}

\footnotetext{
- Visualize and illustrate the failures in the processes; Identify the actors of the activities;

Distinguish the necessary materials and processes;

Inventory the product stock;

- Apply a model of operational policies for the effective management of activities and processes;
}

Through the identified failures and errors, the process model reformulation was developed for each critical phase mentioned above. Always taking into account the needs, ambitions and characteristics of that company. The main objective of inventory management is to provide better results for the institution through:

- $\quad$ Better use of physical space;

- Preservation of quality;

- Cost reduction;

- Financial return on investments.

\section{RESULTS AND DISCUSSIONS}

Data collection and analysis: The company XYZ, has the current stock composed of 855 types of products, in the total quantity of 15168 items in stock. These were grouped by price ranges and product family to simplify the analysis, resulting in 7 classifications. It was observed that some products no longer had a stored value and no information on the entry or exit of those items, those with this evidence were removed from the survey, as the product was either not well required in terms of demand or was no longer found. in the market. Therefore, the list of products in stock was reduced to 545 types of products, but as the prices of these products were already zeroed in the system, the value that was in stock for both situations did not change, and was $\mathrm{R} \$ 557,892,39$, according to the Graph in Figure 4.

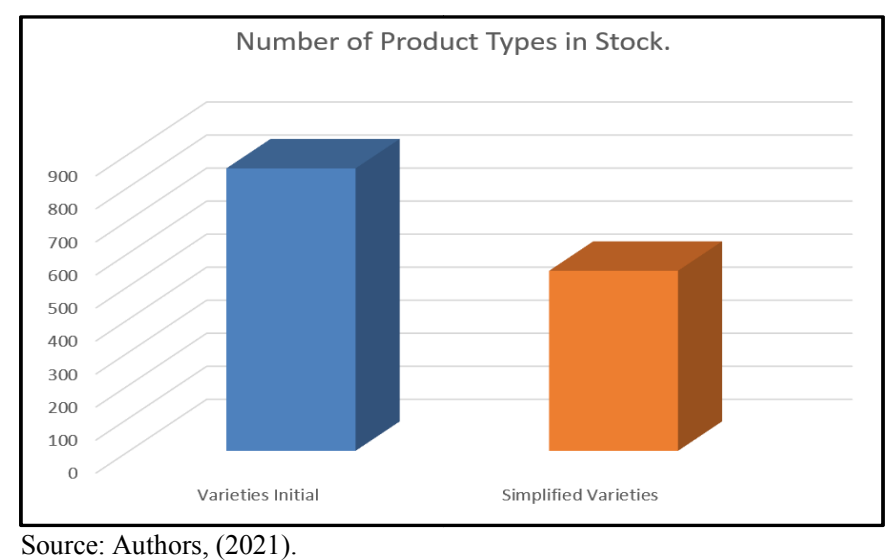

Figure 4 - Types of products

After this simplification, it was also observed that some items that were more than six months old had no record of exits, becoming active stopped. Thus, removing these products from the list, it was noticed a reduction of approximately $5 \%$ of the cost in stock, which corresponds to approximately R \$12,000.0, as shown in the graph in Figure 5.

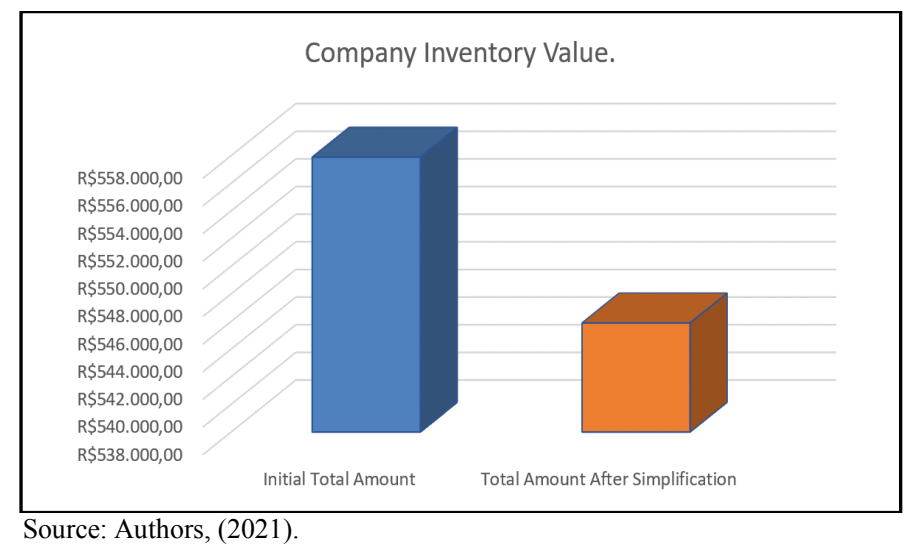

Figure 5. Inventory value

From the simplified stock, approximately $50 \%$ of this total was studied, taking into account the products that were above the average of total sales and those that the company managers said were the ones that most leave the store, that is, those that more sell.

Mapping of processes carried out: Mapping is an important step in defining the scope of the process. Then the FEPSC logical steps were used, clearly described in Table 5. From the analysis of the information collected and with the aid of the logical sequence provided by the FEPSC technique (Table 5.1), the process mapping of the current situation can be constructed. Presented in Table 3.

Three processes were defined that were mapped for inventory management:

- Internal ordering of products.

- Quotation of products.

- Purchase of Products.

Internal product request process and Modeling the internal product request process: The first mapping carried out is defined as an internal product request, which points employees and customers to the logistics and sales sector. 
The process initially consisted of verifying the product's demand, where the input and output list evaluation was carried out to verify the existence or not of demand. This process ended when there was demand, the products on the list in question were quoted with the suppliers. The non-existence of demand causes a new cycle of the internal request process, as shown in figure 6 . It is observed that the process is dynamic, since the list that does not present any demand will be subsequently reassessed.
Thus defined the demand for each product, the members of this process who are employees allocated to the warehouse and sales sector, among others, will be able to request only the products necessary to meet the said demand. Knowing that the demand determines an average and not the exact value, it is necessary to calculate this variation from one period to another. This dispersion is called the standard deviation, which is calculated according to equation (3), which consists of the relationship between demand and

Table 2. Steps for using FEPSC

\begin{tabular}{|l|l|}
\hline Items & \multicolumn{1}{c|}{ Coverage } \\
\hline Determine the purpose & Evidence the existence of the process, what are its objectives and results. \\
\hline Output analysis & Proposes to obtain which products are in process, their outputs and the end of the process in question \\
\hline Customer data & Determines who uses the process products and who are the customers. \\
\hline Analysis of entries and suppliers & $\begin{array}{l}\text { It means collecting and analyzing the information or material to which they work and who provides } \\
\text { them, the suppliers who make them available, where they affect the process flow and what effect it has } \\
\text { on the process and its results. }\end{array}$ \\
\hline Determine the process steps & It means analyzing what happens in each input and what are the actions of transformation of that input. \\
\hline
\end{tabular}

Table 3. Process Mapping

\begin{tabular}{|l|l|l|l|l|}
\hline Providers & Inputs & Law Suit & Outputs & Customers \\
\hline Employees & Listing of product requests. & Internal ordering of products. & Listed products. & Purchasing industry. \\
\hline Manager & List of products to be quoted. & Quotation of products. & Purchase requests. & Warehouse sector. \\
\hline Owner & Quote Response products. & Purchase of Products. & Material delivered. & Sales Sector. \\
\cline { 4 - 5 } & & & Final costumer. \\
\hline
\end{tabular}

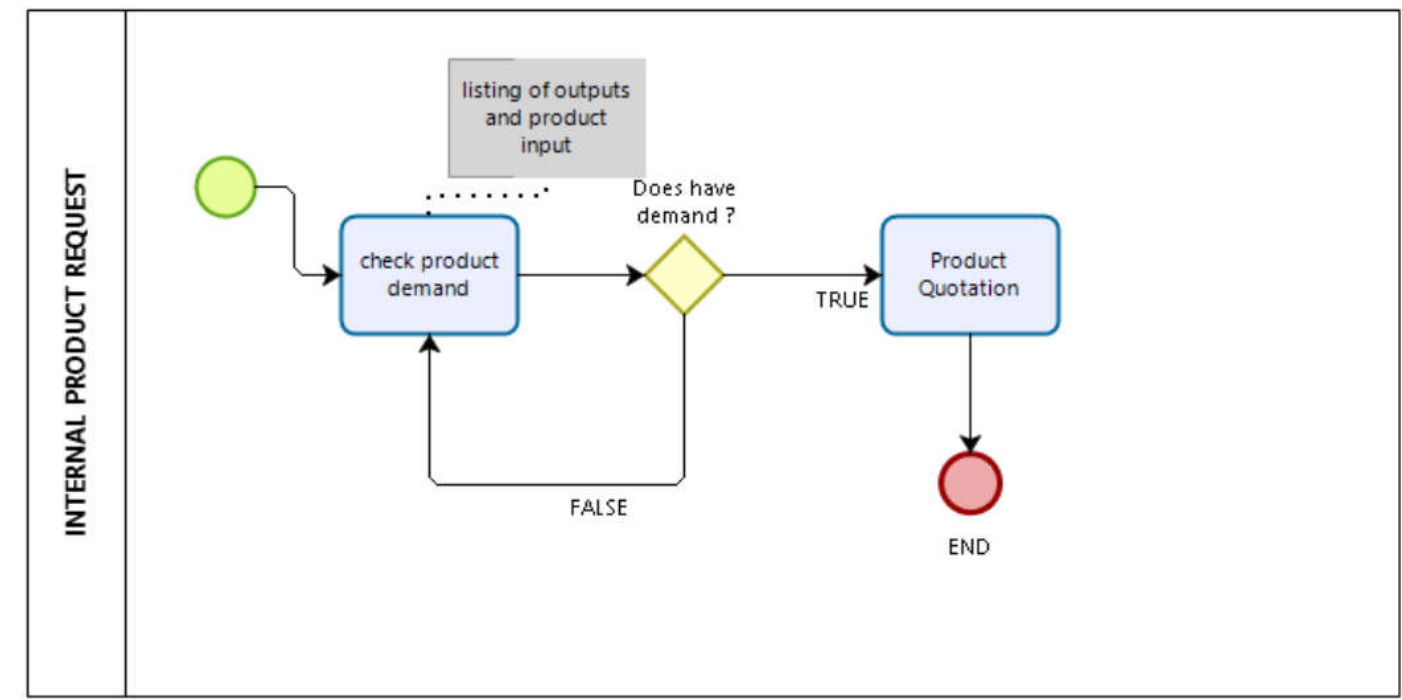

Source: Authors, (2021).

Figure 6. Internal Product Request Mapping

Remodeling of the internal product ordering process: From the discussions of the internal product ordering process, the possibility of improving the organization of the employees' daily lives was verified, in this process the problem was found that when verifying the demand. Employees did not have data such as average demand, where it was proposed to calculate this data on a quarterly basis in order to obtain a confidence margin. It was determined that every 15 days the list of products for internal request was checked. Soon, the remodeling of the internal product ordering process was redesigned in five stages. In the first stage, the calculation of the daily average per product was added according to equation (2), that is, the relationship between the number of items of the product for the period in question. To facilitate the understanding of the members, this data was called average demand or consumption. Therefore, the activity consists of quantifying the average consumption of the units of the product required by the number of periods defined here in three months as mentioned above. monthly consumption in the period in question. However, once the product is in the following process of product quotation, it will automatically be removed from the list, as it is already being worked on, thus avoiding unnecessary time costs and for consequently unnecessary purchases. Example (1): Item x achieved a consumption of 372 units in three months. Therefore, the demand will be 124.0 units per month, the figure shows the graph generated for 7 specific products, according to their respective sales figures. Already in possession of the values of demand and monthly consumption, it was possible to calculate the standard deviation of consumption, which is a measure of dispersion that shows how many values scatter between the numbers above or below in relation to the average value according to the equation (3). Example (2): The same item in example (1) shows a standard deviation of consumption equal to 15.5 over a period of three (three) months. For better understanding, a graph was generated, illustrated in Figure 7 with 7 products selected with the calculations performed. 


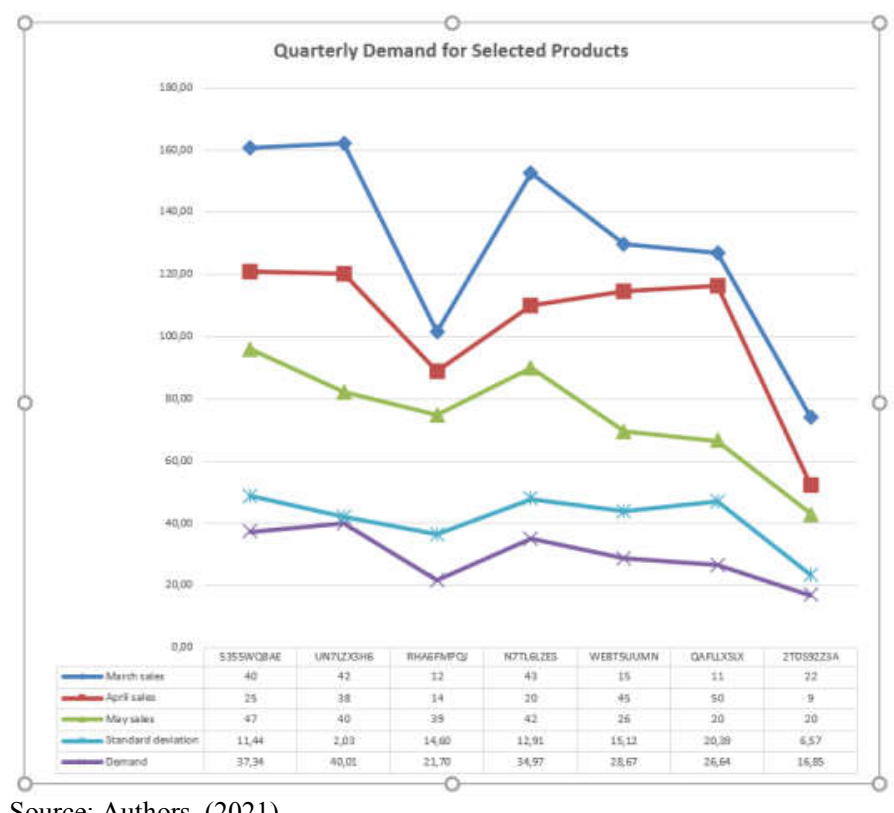

Source: Authors, (2021).

Figure 7. Quarterly demand

Finally, the internal request process was remodeled, as shown in figure 7 , which illustrates all the activities to be adopted, taking into account the improvements described. As soon as the demand, monthly consumption and standard deviation values were known, the second step consisted of surveying the supply time individually for each product from the suppliers. This data is provided directly by the suppliers. It is an eminent value due to the vulnerability. Then, in the third step, it was possible to calculate the value of the minimum stock according to equation (1) which consists of the multiplication between the demand and the coefficient $(\mathrm{k})$, which expresses the level of service or the probability of the stock to meet the demand requested at that time. It was agreed between the company's employees and managers that the degree of attendance would be $95 \%$, which expresses a coefficient $(\mathrm{k})$ of 1.645 . In the fourth phase of this first process, the order point was estimated according to equation (6), which reflects the multiplication between demand and supply time with the sum of the minimum stock, as shown in figure 8 . At that moment we obtain the stock quantity. We completed the internal product order in the fifth phase by executing the product order with the company's internal suppliers:

Example: using the item in example (1) the order point will be R\$ 831.00 .

Therefore, we obtain the values of the coefficient of $\mathrm{k}$ according to table (1) produced from the degrees of service with percentage risks for the 7 products of that company:

Example: The same item as in example (1) has a minimum stock of 25.49. Since the standard deviation is 15.5 and the value of the risk grade coefficient is 1.645 for the degree of care.

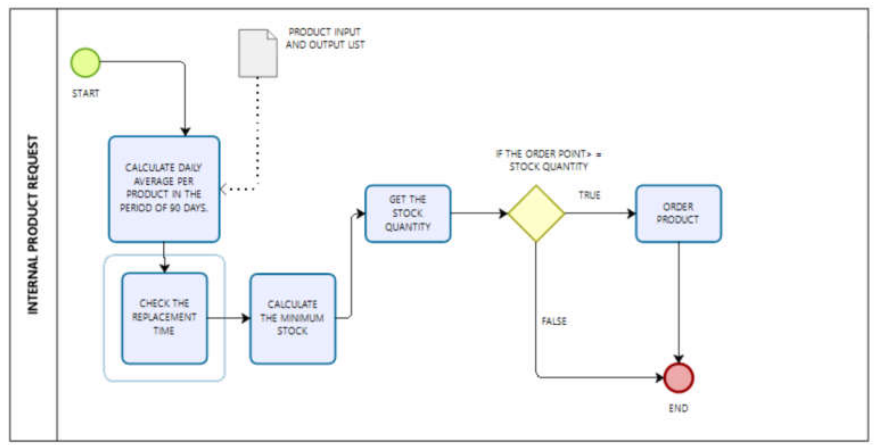

Source: Authors, (2021).

Figure 8. Remodeling of internal product request
Right after applying the remodeling of the internal ordering process, we have the values of important variables such as minimum stock, supply time and the order point for stock management according to table 4. For example, the product code 5355WQ8AE a minimum inventory of 7 products, a two-day supply time and an order point of 65 items. While the product code UN7LZX3H6 has a minimum stock of 5 products, a supply time of one day and an order point of 27 items, we can verify that the greater the demand, the higher the order point.

Table 4. Relationship between the minimum stock and the order point

\begin{tabular}{|l|l|l|l|}
\hline BAR CODE & $\begin{array}{l}\text { MINIMUM } \\
\text { STOCK }\end{array}$ & $\begin{array}{l}\text { SUPPLY } \\
\text { TIME }\end{array}$ & $\begin{array}{l}\text { SCORE } \\
\text { REQUEST }\end{array}$ \\
\hline 5355WQ8AE & 7 & 2 & 65 \\
\hline UN7LZX3H6 & 5 & 1 & 27 \\
\hline RHA6FMPQJ & 7 & 2 & 58 \\
\hline N7TL6LZES & 5 & 2 & 57 \\
\hline WEBT5UUMN & 11 & 2 & 89 \\
\hline QAFLLXSLX & 6 & 2 & 54 \\
\hline 2TDS92Z3A & 6 & 3 & 82 \\
\hline
\end{tabular}

Source: Authors, (2021).

Product Quotation Process and Product Quotation Process Modeling: The second critical process is that of product quotation, which covers the warehouse department as an external supplier and the Department as a customer, where it orders the most diverse products needed for that month. Once, if there is a demand, that is, a positive response from the internal product ordering process. The products were quoted in the first stage by the warehouse department, together with the suppliers. The commercial partners were already known in advance, but the replacement time for each product was not taken into account. In the second moment, we had as a final product the list of products for purchase as illustrated in Figure 9.

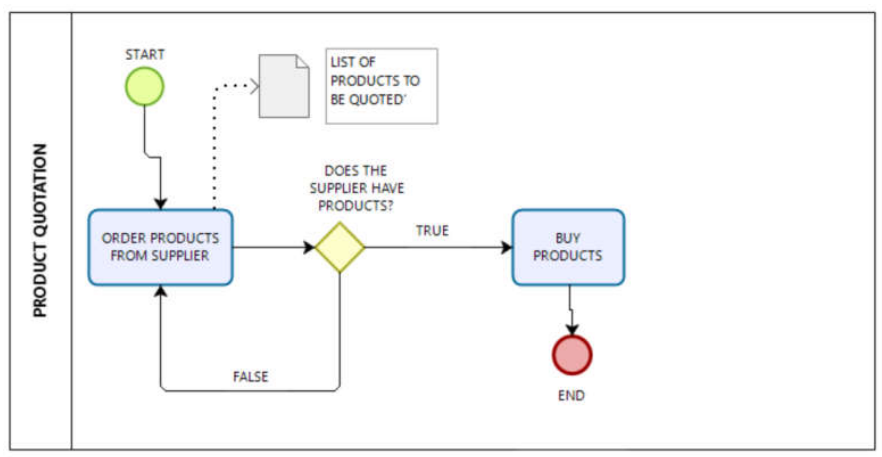

Source: Authors, (2021).

Figure 9. Product Quotation Process

Remodelagem do processo da cotação de produtos: In the product quotation process, the error of not having a product quotation periodicity was identified, where occasionally the company lost control of the inventory, as the supply time by suppliers was not taken into account, as well as the average monthly consumption that had already been defined in the improvement of the previous process, and the level of the safety stock together with the lack of classification of the items individually according to importance for the stock, generating increase of the stock and waste of physical space leading to unnecessary costs . Once the correction of the internal product request process has been defined, the next step represents the reformulation of the Product Quotation process, comprised of five phases. Starts with the evaluation of the list of products to be purchased. In this first moment, it was proposed to calculate the purchase lot according to equation (5), which defined the purchase lot equal to the average consumption. Thus, in possession of the values of the minimum stock and the purchase lot, it was possible to proceed to the second stage, which comprises calculating the maximum stock for each product according to equation (7), which comprises the sum between the minimum stock 
and the shopping lot. However, the third step of the process is of paramount importance to assess the minimum stock and check for past arrears. Because, the sum of the current batch plus the overdue order can express a totality greater than the maximum stock value, causing excess product storage. Therefore, the current purchase lot will only proceed to the fourth stage of the lot quote if and only if the sum of the lot in question plus the overdue lot is less than or equal to the maximum stock. If the sum of the lot plus the previous overdue order is greater than the maximum stock, the quotation will be based on the value of the minimum stock. As shown in the fifth phase. Avoiding the number of excess orders, increase in purchases, increase in items in inventory and, consequently, financial losses. In this step, the safety stock was calculated according to equation (8), which represents the square root of the product among the variables average demand, supply time, standard deviation and safety coefficient. This data aims to ensure the stock at the expense of variations in supply time and seasonality. As shown in figure 10, we have the dimensioning of the stock drawn through the numerical values of the safety stock and maximum stock. For example, product code 5355WQ8AE has a security stock of 7 items and a maximum stock of 35 items. But remembering that these values constantly need to be reassessed, since the market is dynamic, the demand for the product may grow or even decrease. In more distant locations the supply time varies constantly.

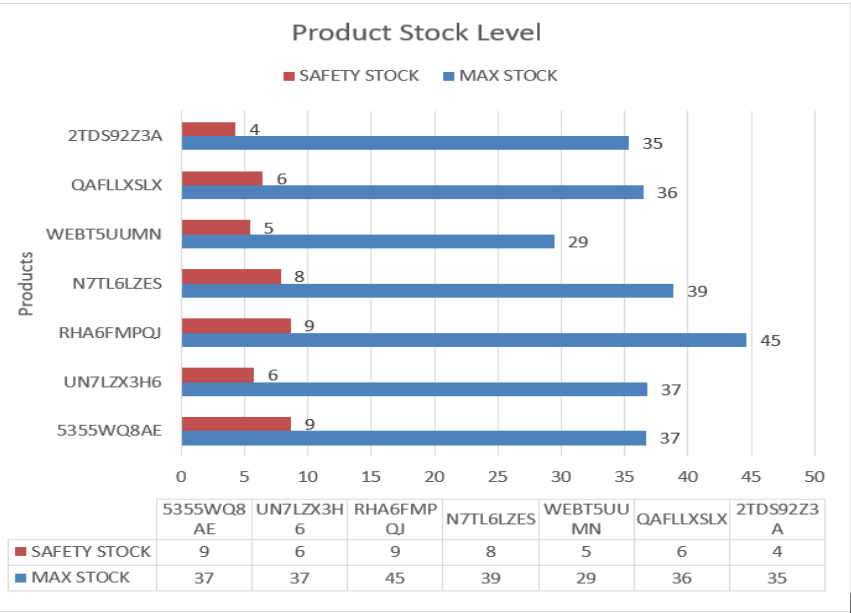

Source: Authors, (2021).

Figure 10. Inventory level

Figure 11 explains the remodeling of the product quotation process, which includes the warehouse department as an external supplier and the Department as a customer, where the purchase lot values also defined as demand and the maximum stock value are computed. Finally, the remodeling of the quotation of the product focuses on calculating and studying the numerical values of the most important variables for stock management. This data in this stage comprises the purchase lot, the maximum stock and the safety stock together with the assessment of the minimum stock and the demand already calculated in the remodeling of the product's internal quotation. At this stage of the process, the company can claim that it knows the size of the stock, once I know the values of demand, order point, minimum stock and maximum stock. This knowledge produces a basis for the decision to quote or not a lot. Therefore, avoiding unnecessary expenses with full stock and possible financial losses. Therefore, if the value of the purchase lot plus the sum of the previous lot does not exceed the value of the maximum stock. The aforementioned process signals the purchase lot quotation in a positive way. It is observed that the values of the variables already calculated in the remodeling stages of the internal request of the product and the remodeling of the quotation of the product are filed, because during the management of the stock these data are continuously evaluated. Because these provide accurate information for the best decision making.

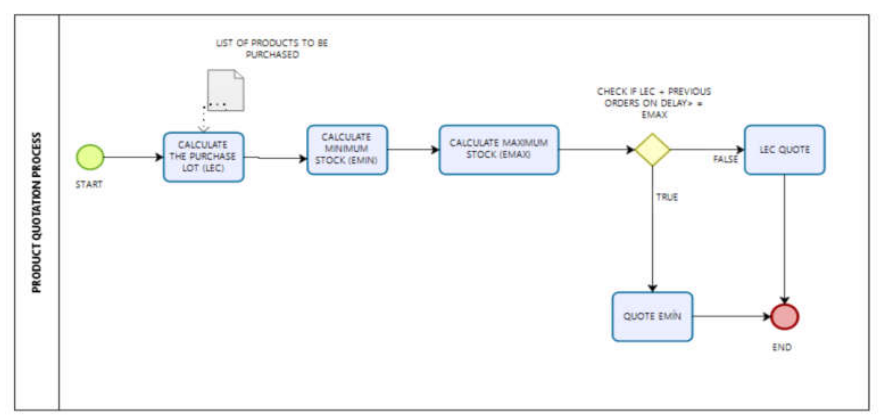

Source: Authors, (2021).

\section{Figure 11. Remodeling of the product quotation}

Therefore, once the product stops by the internal request stages, having the approval of the existence of demand and later goes through the second process, which is the quotation, receiving a positive response in front of the suppliers. This item is ready to enter the purchase phase.

Product Buying Process and Modeling: So the last critical process demonstrates the final step that is performed periodically is the purchase of products carried out together with the manager and the employees according to the demand obtained by counting the entry and exit of items. In the first stage of the process, we had the list of products to be purchased. Then the final stage was reached, which consisted of making the purchase of the products effective. It is observed that the processes were carried out in stages taking into account each activity within the final process, which is the purchase of products, which should take into account the delivery time of each ordered item. Therefore, the modeling of the product purchase process is shown in figure 12 .

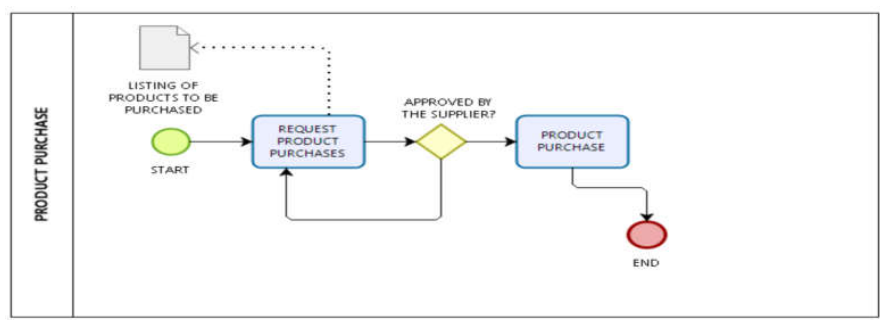

Source:Authors, (2021).

Figure 12. Product Purchase Modeling

Remodeling of the product purchase process: Finally, in the last product purchase process, there was a lack of storage of the product delivery time, which had helped in the solution of the previous process. In the purchase process, which comprises three stages. The proposed improvement also encompasses the storage of order data to assist in the two previous processes in the management of inventory control. These data comprise the order date, the order status, product unit value, product quantity, supply time and supplier information. Generating reports that aided decisions regarding inventory management. Therefore, it is possible to manage the products according to the degree of importance based on the investments in each of the items. Thus, using the ABC Curve for easy identification of products that should receive special attention regarding their management. The first step consisted of applying the ABC curve, as it demonstrates the financial importance of each product for inventory management. This data is fundamental, because, I allowed the identification of products that should give more attention on the part of the administrators. Not depressing the zeal of the management of other products. 
Thus, we can verify the $\mathrm{ABC}$ curve, through figure 13 of the products analyzed in this work.

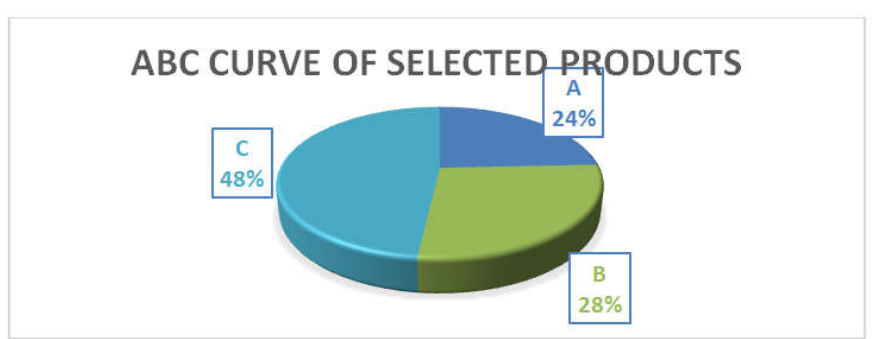

Source: Authors, (2021).

\section{Figure 13. Graph of the ABC Curve of the products that were sampled}

The product purchase process was remodeled as shown in figure 14 . The second stage, expressing a critical moment, of whether or not the product was actually purchased. This final step is carried out every 15 days. This frequency was agreed between the manager and employees responsible for managing the inventory based on the average consumption calculated by counting the entry and exit of items. The methods are carried out in stages taking into account each activity within the final process, which is the purchase of products. Once the batch is approved, it passes to the product purchase stage. Recalling that this lot was quoted with the suppliers. Because the actual purchase of the product also occurs in line with the supply time of each item, the responsibility of which is the responsibility of the suppliers. Therefore, in the third step of the process, we emphasize the importance of storing the purchase / order history. Since, the retention of variables applied at work helps employees and managers to understand the dynamics of consumption, starting to control inventory efficiently.

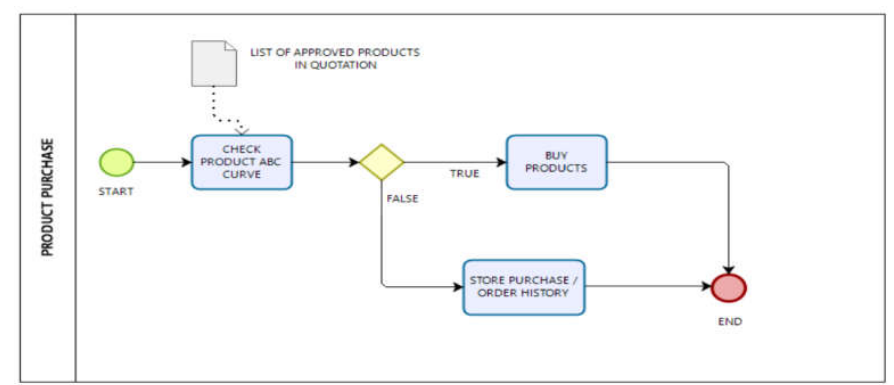

Source: Authors, (2021).

\section{Figure 14. Remodeling of product purchase}

Final proposal of the methodology: Therefore, based on the analysis of pre-existing stock management and studies of the theoretical framework, it was possible to propose a methodology for optimizing stock control, having as reference mathematical equations already studied in the stock management project. The proposed methodology was developed taking into account the most imminent and precise variables, emphasizing each phase of the processes. And so, offering reliable and authentic data for each sector, optimizing the management process. Following is an explanation of the proposed methodology.

1st Stage: Calculate the monthly average of the items based on the last 90 days.

$C m d=(\Sigma C) / n$

Where:

Cmd $=$ Average monthly consumption;

$C=$ Monthly item consumption;

$n=$ Number of periods.
Calculate the standard deviation of consumption

$\delta=\sqrt{\frac{\sum_{i=1}^{n} \quad(C-C m d) 2}{n-1}}$

Where:

$\delta=$ Standard deviation of consumption;

$\mathrm{C}=$ Monthly item consumption;

$C \mathrm{md}=$ Average monthly consumption;

$n=$ Number of periods.

Survey supply time, data obtained from suppliers

Calculate the minimum stock.

Emin $=\operatorname{Cmd} x K$

Where:

Emin $=$ minimum stock.

$\mathrm{Cmd}=$ Average monthly consumption

$\mathrm{K}=$ Degree of risk, that is, desired degree of coverage.

Calculate the Order Point

$P P=(C x T R)+E \min$

Where:

$\mathrm{PP}=$ Order point;

$\mathrm{C}=$ Monthly item consumption;

$\mathrm{TR}=$ Resupply time;

Emín=Minimum stock

2nd Stage: Calculate the purchase lot.

$L C=C m d$

Where:

Cmd $=$ Average monthly consumption

Calculate the maximum stock

$E m a ́ x=E S+L E C$

Where:

Emin $=$ minimum stock

$\mathrm{Lec}=\mathrm{CMm}$.

Calculate Safety Stock......ES $=\sqrt{L T *\left(\sigma_{d}\right)^{2}+d^{2} *\left(\sigma_{L T}\right)^{2}} *$ K... (8)

Where:

$E s=$ Reserve or safety stock;

$\mathrm{d}=$ average demand;

LT= supply time;

$\mathrm{d}=$ consumption standard deviation;

$\mathrm{k}=$ safety factor;

$\sigma=$ sigma

\section{3rd Stage: ABC Curve Formulation}

Satisfactory results: One of the objectives of the entire company is to maximize profits, and it is understood that a fundamental part of this is profit on the capital adopted in its stock. And for that it is necessary to reduce the number of products in stock stored, in view of this scenario it is essential that companies adopt plans to have essential information for decision making. From the case study presented, the 
objectives proposed by this work were achieved insofar as the existing problems were analyzed and through the help of the tools implemented in the new activities of the process. In a period of 3 months after the implementation of this, it was noticed that the place was organized, the products are in easy handling with the reduction of about $30 \%$ the problem of non-service to customers. With these processes, the costs of purchasing and managing inventories are seen as the main results of the study that allow greater optimization of store activities in relation to the organization. It takes into account the benefit can be a facilitation of a possible systematization and regulation of the company's inventory policy. Offering the periodic control of the results, as well as in the identification of the weaknesses in the process, thus sympathizing for the continuous improvement of several aspects of the organization. Because decisions in an institution are discussed daily, and therefore solid, reliable and authentic data must be taken in order for the organization to achieve its objectives, in order to support this decision making is that inventory management works. With the literature review, the critical management problems that are identified in micro and small companies that point to inventory management were analyzed. From this, the types of operational management controls in the literature were studied and identified to those pertinent to the company, and how to apply them.

The new modeling adopted, facilitated the analysis of the products that were in and as well as in the activities that are linked to the inventories, gains as the satisfaction of the collaborators for executing their functions in an optimized and flexible space; in addition to customer loyalty motivated by improved service. Currently, the permanent lack of reliability in relation to the price of products makes purchasing managers or teams in the purchasing sector want to tax the stocked goods at lower prices, but an organized stock is required by the manager. The inventory control carried out in this project showed an improvement in the stock flow, since the system warns that the product is out of stock, so that the responsible sector is able to buy and, consequently, I quickly purchased the product so that it can reduce the loss of sales to customers. consumers, making them loyal. Thus, it was also possible to identify in the application of the maximum-minimum stock method in the store, how much of the financial resources that were stopped had in the form of inventory, such resources that should be applied or in other activities that could generate profits. With the risk of vulnerability of the lag or devaluation of the product they suffer in the daily market, assuming a possibility of not meeting the demand in certain months, concerning the lack of methods to establish their order point levels, safety stock, etc. However, during the elaboration and application of the project, an obstacle found for the implementation was the difficulty of accepting and adapting the changes proposed by the employees, which was overcome with the dialogue and with the presentation of the results found in the adopted literature. Another problem was the resistance of some suppliers in relation to the deadlines stipulated by the Purchase Department, but they recognized the importance of the new management implemented.

\section{CONCLUSIONS}

Finally, the project contributed not only to the management of the stores, but also, however, with importance to activities related to the employees responsible for executing them. Thus, the participation of all those involved was clearly evident, giving due importance with due commitment. The actions to identify and model the inventory control processes that already exist in the company allowed the recognition of worthless stocked products and the absence of information on item entries or exits of the sector already mentioned. With the analysis of the pre-existing stock in the organization, the flaws in the management process were identified as well as the lack of knowledge on the part of the employees about the stock control management. Right after the analysis, the description of the methodology provided the identification of the improvements to rectify the erroneous activities of the stock, signaling the benefits for each operation in the referred management. The implementation of the proposed methodology for the optimization of inventory control ensured positive results such as lean inventory, efficient customer service, increased capital turnover and increased company profits. Assuming that for the store to guarantee its continuity in this competitive market, it will have to continue and improve its maximum-minimum stock management methods, such as, for example, acquiring more complete and computerized management systems to enable improvements and achieve new knowledge and techniques for obtain better results, complying with other expanding methods for the other processes of the organization. It is recommended an investment in updated research inherent to cargo logistics in the electronics industry. This segment in the industry of the city of Manaus constantly suffers from logistics, since the distance of this region in relation to the major economic centers and the deficient transport network increases the costs of products and the time to replenish stocks. Another recommendation for future work is to examine the applicability of the vast literature on inventory management. Regarding the development of more compliant inventory management models. Thus, making inventory management more accessible to managers.

\section{REFERENCES}

ABINEE, Desempenho Setorial -Decon- Abinee. 2019. Disponível em: $\quad<$ http://www.abinee.org.br/abinee/decon/decon15.htm>. Acesso em: 16 set. 2019.

Vollman, E.T. et al. Sistemas de Planejamento \& Controle da Produção para o Gerenciamento da Cadeia de Suprimentos. $5^{\text {a }}$ ed. Porto Alegre: Bookman, 2006.

Borges, C. T.; Campos S. M.; Borges C. E. 'Implantação de um sistema para o controle de estoques em uma gráfica/editora de uma universidade". Revista Eletrônica Produção \& Engenharia, v. 3, n. 1, pp 236-247, 2010.

Plaza, M., David, I., Shrazi, F., Management of Inventory Under Market Fluctuations the Case of a Canadian High Tech Company. International Journal of Production Economics, 2018.

Wernke, R.; Lembeck, M.; Nascimento, F. A. Gestão financeira de estoques: estudo de caso em indústria têxtil de médio porte. Revista brasileira de contabilidade. Rio de Janeiro, v. 40, n. 190, pp. 65-75, 2011.

Rodrigues, P. C. C.; Marins, F. A. S.; Souza, F. B.; Proposta de um Modelo Matemático para a Minimização dos Estoques de Matérias-primas. Iberoamerican Journal of Project Management .v. 7, n.1, pp. 01-21, 2016.

Chiavenato, I. Gestão de Pessoas: O Novo Papel dos Recursos Humanos nas Organizações. 4. ed. Barueri: Manole, 2014.

De vos, B.; Raa, B.; Stability Analysis of Cost Allocation Methods for Inventory Routing. International Federation of Automatic Control. pp 1682-1688, 2018.

Martelli, L. L.; Dandaro, F. Planejamento e Controle de Estoque nas Organizações. Revista Gestão Industrial, v. 11, n. 02: p. 170$185,2015$.

Pozo, H. Administração de Recursos Materiais e Patrimoniais: Uma Abordagem Logística. 6. ed. São Paulo: Atlas, 2010.

Kok, T. Inventory Management: Modeling Real-life Supply Chains and Empirical Validit. Information and Operations Management: v. 11, n. 4, pp. 343-437, 2018.

Krajewski, L.; Ritzman, L.; Malhotra, M. Administração de Produção e Operações. 8. ed. São Paulo: Pearson Prentice Hall, 2010.

Moreira, D. Administração da Produção e Operações. 2.ed. São Paulo: Cengage Learning, 2016.

Francischini, P. G.; Gurgel F. A. Administração de Materiais do Patrimônio. São Paulo: Pioneira Thomson, 2004.

Arnold, J. R. T. Administração de Materiais. 2. ed. São Paulo: Atlas, 2014.

Bowersox, D. J.; Closs, D. J. Logística Empresarial: O Processo de Integração da Cadeia de Suprimentos. São Paulo: Atlas, 2018.

Rushton, A.; Croucher, P.; Baker, P.; The Handbook of Logistics and Distribution Management. 3. ed. London, 2006.

Santos, A. M.; Rodrigues, I. A.; Controle de Estoque de Materiais com Diferentes Padrões de Demanda: Estudo de Caso em uma 
Indústria Química. Gestão \& Produção, v.13, n. 2, pp.223-231, 2006.

Cecatto, C.; Belfiore, P. O Uso de Métodos de Previsão de Demanda nas Indústrias Alimentícias Brasileiras. Gestão \& Produção, v. 22, n. 2, pp. 404- 418, 2015.

Kumawat, R.; et al.; Mathematical Modelling of Inventory Management, 2017.

Bertaglia, P. R. Logística e Gerenciamento da Cadeia de Abastecimento. 2. ed. rev. e atual. São Paulo: Saraiva, 2009.

Li, Z.; Sun, S.; Huang, Y.; Exploring Inventory Order Policies Impact Under the Non-Negative Constraint of Order Quantity: System Stability, Service Level, and Cos. Journal Solitons And Fractals, n. 103, pp. 111-122, 2017.

Magalhães, O. A. Modelagem matemática para gestão de estoque de múltiplos itens com demanda derivada em um hospital de médio porte. Faculdade Federal Ouro Preto, Ouro Preto, 2016.

Spagnol, W. A. et al.; Redução de Perdas nas Cadeias de Frutas e Hortaliças pela Análise da Vida Útil Dinâmica. Brazilian Journal Food Technology, v. 21, 2018.

Novaes, A.G. Logística e gerenciamento da cadeia de distribuição. 3. ed., Rio de Janeiro, Campus, 2007.

Sutrisno; Widowati; Munawwaroh, A. D.; Hybrid Mathematical Model of Inventory System with Piecewise Holding Cost and Its Optimal Strategy. International Conference on Advanced Mechatronics, Intelligent Manufacture, and Industrial Automation , pp. 29-33, 15-16 October, 2015.

Rahdar, M.; Wang, L.;Hu, G.; A tri-level Optimization Model for Inventory Control With Uncertain Demand and Lead Time. International Journal of Production Economics, 2017.

Gupta, S. Just in Time Manufacturing: A Manufacturing Philosophy, Journal of Scientific and Technical Advancements, v. 1, n. 3, pp. 241-244, 2015.

Pasquali, F. D. O Sistema JUST-IN-TIME (JIT) um Estudo de Caso: Produção em Série de Móveis de Madeira. Universidade Federal De Santa Catarina (UFSC). Centro Sócio Econômico, Departamento De Ciências Contábeis, 2010.

Kaminski, M. T., de Oliveira, J. H. R., Ribeiro, R. P., de Oliveira, R. M., \& Siluk, M. H. P. Um Estudo da Viabilidade de Implementação do Just in Time na Santa Fé Vagões S/A, 2010.

Bhowmik, T.; ReddivarI, S. Resolution Trend of Just-in-Time Requirements in Open Source Software Development. School of Computing, University of North Florida, Jacksonville, FL, USA, 2015.

Gitman, L. J. Princípios de administração financeira. 7. ed. São Paulo: Harbra, 2002.

Chopra, S.; Meindl, P. Gerenciamento da cadeia de suprimentos: estratégia, planejamento e operação. São Paulo: Prentice Hall, 2012.

Dias, M. A. P. Administração de Materiais: Princípios, Conceitos e Gestão. 6. ed. São Paulo: Atlas, 2012.

Slack, N.; Chambers, S.; Johnston, R. Administração da Produção. 4. ed. São Paulo: Atlas, 2014

Neves, S. Contabilidade Avançada e Análise das Demonstrações Financeiras. 18. ed. São Paulo: Saraivauni, 2017.

Zoppei R. A.; Santos I. L.; Vinotti C. A. An Inventory Management Proposal for a Metallurgical Industry. Braz. J. of Developer, Curitiba, v. 4, no 4, pp. 1343-1358, 2018.

Santos, S. A. S.; Viana, A. S.; Gerenciamento da Cadeia de Suprimentos - Supply Chain Management a Busca pela Vantagem Competitiva. Interfaces Científicas - Exatas e Tecnológicas, v.1, n.1, pp. 41-51, 2015.

Machado, M. C. Gestão de Operações V, 2013.

Corrêa, H. L. Gestão de redes de suprimento: integrando cadeias de suprimento no mundo globalizado. São Paulo: Atlas, 2010.

Marins, F. A. S. Técnicas de Previsão. São Paulo: Unesp, 2011.

Gontijo, T.; et al.; Consumo Industrial de Energia Elétrica: Um Estudo Comparativo entre Métodos Preditivos. Brazilian Journal of Production Engineering, v. 3, n. 3, pp. 31-45, 2017.

Hoppe, M.: Inventory Optimization with SAP, Galileo Press, pp. 335404, 2008.

Tubino, D. F. Manual de Planejamento e Controle da Produção. 2. ed. São Paulo: Atlas, 2006.
Gonçalves, P. S. Administração de materiais. Rio de Janeiro: Elsevier, 2007.

Martins, P. G.; Laugeni, F. P. Administração da Produção e Operações. São Paulo: Saraiva, 2009.

Hara, C. M. Administração de Recursos Materiais e Patrimoniais. Campinas: Alínea, 2012.

Lustosa, L.; et al.; Planejamento e controle da Produção. Rio de Janeiro: Editora Elsevier, 2008.

Taylor, A. D. Logística na Cadeia de Suprimentos uma Perspectiva Gerencial. São Paulo: Pearson, 2006.

Martins, P. G.; Alt, P. R. C. Administração de Materiais e Recursos Patrimoniais. 3. ed. São Paulo: Saraiva, 2009.

Araújo G. C.; Silva J. P. Z.; Souza L. R.; Loureiro M. B.; Feroni R. C. Previsão de Demanda e Análise Simplificada da Gestão de Estoque Aplicada a Uma Empresa do Setor Alimentício. Brazilian Journal of Production Engineering, São Mateus, v. 4, n. 2 , p. $48-64,2018$.

Yijun, H.; Jingjing, W. Study on Safety Stock Control Based on System Dynamics. International Conference on Service Systems and Service Management, Beijing, China 25-27 june, 2014.

Hillebrand, L.H. Proposta de Modelos para Gestão de Estoques das Principais Matérias-primas Utilizadas no Processo Produtivo de Condimentos Alimentícios. CENTRO UNIVERSITÁRIO UNIVATES, 2016.

Wild, T. Best Practice in Inventory Management. 3. ed. New York: Routledge, 2017.

Maria, G. B. A; Novaes, A. G. N. Determinação do estoque de segurança baseado em confiabilidade produtiva. ENEGEP XXXI Encontro nacional de Engenharia da Produção, Belo Horizonte, 2011.

Rădăşanu, A. C. Inventory Management, Service Level and Safety Stock, Alexandru Ioan Cuza University, Iaşi, Romania, 2016.

Moreira, D. Administração da Produção e Operações. 2.ed. São Paulo: Cengage Learning, 2016.

Oliveira, R.E.; Melo, J. A. M. A Relevância Das Ferramentas De Gestão De Estoques -Um Estudo de Caso em uma Empresa do Mercado Gráfico. Revista Negócios em Projeção, v.6, n.1 ,p p. 69-90, 2015.

Jacobsen, M. Logística Empresarial. UNIVALI., 2009.

Cardoso, F. S.; LIMA, J. D. R., FREITAS, F. F. T. Gestão de Estoque: Aplicação de Técnicas para Auxilio à Tomada de Decisões no Setor de Compras em uma Distribuidora de Medicamentos e Material Hospitalar. XVIII Simpósio de Engenharia de Produção. SIMPEP. Bauru, SP, Novembro, 2011.

Vago, F. R. M. et. al. A Importância do Gerenciamento de Estoque por Meio da Ferramenta Curva ABC. SOCIAIS E HUMANAS, SANTA MARIA, v. 26, n. 03, pp. 638 - 655, 2013.

Aragão, A.M.S.; et al.; Aplicação da Curva ABC em uma Empresa do Setor Atacadista no Estado de Sergipe. XXXVI Encontro Nacional de Engenharia de Produção, João Pessoa, Brasil, Outubro, 2016.

Eleodoro, L. S.; et al.; Cálculo do Lote Econômico de Compra de Matérias-Primas Utilizadas no Processo de Tratamento de Água Considerando os Estoques de Segurança e o Lead Time dos Fornecedores. Anais do XXXIII ENEGEP; Salvador, BA, 2013.

Marshall junior, I.; Cierco, A. A.; Rocha, A. V.; Mota, E. B.; Leusin, S. Gestão da Qualidade. 8. ed. Rio de Janeiro: FGV, 2008.

Mello, A. E. N. S. Aplicação do Mapeamento de Processos e da Simulação no Desenvolvimento de Projetos de Processos Produtivos. 2008.

Lucas, A. S.; et al.; Mapeamento de Processos: Um Estudo no Ramo de Serviços IJIE: Revista Iberoamericana de Engenharia Industrial. Florianópolis v. 7, 2015.

Oliveira, M.; Freitas, H. Seleção de Indicadores para Tomada de Decisões: A Percepção dos Principais Intervenientes na Construção Civil. Edição Especial Impressa, pp. 24, v. 7, nº 6, 2001.

Antonucci, Y. L., et al.; Business Process Management Common Body of Knowledge, Terre Haute, ABPMP, 2009.

Bowles, D.E. and Gardiner, L.R.,Supporting process improvements with process mapping and system dynamics, International 
Journal of Productivity and Performance Management, v. 67, n. 8, pp. 1255-1270, 2018.

Bouer, G. et al. Gestão da Qualidade: Teoria e casos. Elsevier Brasil, 2016.

Castellanelli, C. A. Mental Models and Systems Thinking: Challenges of Strategic Analysis of Business Processes in Organizations. Revista Espacios, v. 38, pp 1, 2017.

Sarimveis, H.; et al.; Dynamic Modeling and Control of Supply Chain Systems: A Review. Computers \& Operations Research, v. 35 , n. 11 , pp. $3530-356,2008$.

Costa, L. Formulação de uma metodologia de modelagem de processos de negócio para implementação de workflow. Universidade Tecnológica Federal do Paraná, Ponta Grossa, 2009.
Alves, F. B. Processos organizacionais: simplificação e racionalização. 1. ed. São Paulo: Atlas, 2011.

Biazzo, S. Process Mapping Techniques and Organizational Analysis: Lessons from Sociotechnical System Theory. Business Process Management Journal, v. 8, n. 1, p. 42-52, 2002.

Paula, M. A. de; Valls, V. M. Mapeamento de processos em bibliotecas: revisão de literatura e apresentação de metodologias. Revista Digital de Biblioteconomia e Ciência da Informação, Campinas, v. 12, n. 3, pp. 136-156, set./dez. 2014..

Laurindo, F. J. B.; Rotondaro, R. G. Gestão integrada de processos e da tecnologia da informação. São Paulo: Atlas, 2011.

Vianna, W.B. O Design da Pesquisa Qualitativa: Questões a Considerar. In.: Anais do XIII Simpósio de Engenharia de Produção, 2006 